\title{
Idän monikielisyyttä ennen ja nyt
}

Leena Kolehmainen, Helka Riionheimo \& Milla Uusitupa (toim.): Ääniä idästä. Näkökulmia ItäSuomen monikielisyyteen. Suomalaisen Kirjallisuuden Seuran toimituksia 1461. Suomalaisen Kirjallisuuden Seura, Helsinki 2020. 331 s. ISBN 978-951-858-206-2.

Ääniä idästä -artikkelikokoelman taustalla on halu haastaa käsitys Itä-Suomen yksikielisyydestä, ja sen keskeisimmäksi tavoitteeksi mainitaankin "yksikielisyyden harhaksi” nimetyn myytin purkaminen. Erityisesti historiallisesta näkökulmasta Itä-Suomen monikielisyys näyttäytyy monitahoisena; sodat ja rajojen siirrot ovat vaikuttaneet paljon eri kielten puhujien vuorovaikutukseen. Teos on kiinnostava yhdistelmä selvästi tunnistettavaa paikallisväriä ja laajempia ilmiöitä, joilla kuitenkin kaikilla on kytkös nykyiseen tai sotia edeltävään Itä-Suomeen. Perusteellisessa johdannossa toimittajat esittelevät teoksen tulokulmia lähtien Kalevalasta, joka on monikielinen kollaasi, vaikka näyttäytyy usein yksikielisesti suomenkielisenä. Samaan tapaan ItäSuomi on rakentunut kaukaa katsoen yksikieliseksi. Lisäksi esitellään kielitilastoja, kielellistä historiaa ja teoksen artikkelien näkökulmia. Artikkeleissa ei käsitellä vain monikielistymistä vaan myös sen vastakohtaa, kielellisen monimuotoisuuden kaventumista. Esiin otetaan myös eettiset kysymykset henkilötietojen suojaamisesta tutkijanposition tarkasteluun; toimittajat painottavat aiheellisesti, kuinka tutkijan on syytä pysähtyä aika ajoin pohtimaan tulkintoihinsa päätymistä tai aineistoesimerkkien valintaa, olivat kyseessä sitten nykyiset sosiaalisen median aineistot tai vanhat tekstit.

Kirja on johdannon jälkeen jaettu kolmeen osaan artikkelien käsittelemien aineistojen perusteella. Ensimmäinen osa "Kentällä - kohtaamisia kielten puhujien kanssa" koostuu kolmesta artikkelista, joissa tarkasteltavana ovat kieltenpuhujilta kerätyt aineistot ja myös itse tutkimusprosessi. Toisessa osassa, joka on varustettu otsikolla "Luettua ja tulkittua - lähteenä päiväkirjat, elämäkerrat ja historiankirjoitus", tarkastellaan historiaa erilaisten kirjallisten aineistojen valossa. Kirjan viimeisessä osassa "Kirjoitettuja jälkiä - kohteena kielimaiseman lyhyet tekstit" yhdistävänä tekijänä on erityisesti aineistona olevien tekstien lyhyys ja se, että ne ovat kirjoitettuja: toiset digitaalisesti somessa, toiset fyysisesti materiaan tallennettuina hautamuistomerkeissä ja tutkimusaineistona niistä otetuissa valokuvissa. Rakenne vaikuttaa tarkasti harkitulta, ja se itsessään avaa uusia näkökulmia ja palvelee yhtä kirjan päämääristä, joka on tehdä näkymätöntä monikielisyyttä näkyväksi. 


\section{Kielenkäyttäjien erilaiset kieliresurssit}

Ensimmäisen osan avaava Helka Riionheimon ja Marjatta Palanderin artikkeli käsittelee sitä, kuinka kolme rajakarjalaistaustaista ilomantsilaista ovat säilyttäneet muistikuvia elämänsä käänteissä kuulemastaan karjalasta. Kirjoittajat myös kuvaavat niitä strategioita, joiden avulla karjala on säilynyt puhujien mielissä. Artikkelissa tarkasteltavat puhujat on valikoitu laajemmasta aineistosta sillä perusteella, että he tuottivat haastatteluissa pitkiä karjalankielisiä puhejaksoja. Taitavien imitoijien ja karjalaa säilyttäneiden puhujien valinta palveleekin parhaiten artikkelin tavoitetta. Aiemmissa tutkimuksissa laajaa aineistoa on käsitelty anonyymisti, mutta tässä artikkelissa tutkittavat esiintyvät omilla nimillään ja kasvoillaan, koska tunnistettavuus on ilmeistä tällaisessa elämänvaiheisiin kiinnittyvässä tarkastelussa. Tekijät kuvaavat kirjoittaneensa artikkelin kunnioittaakseen ja kiittääkseen näitä ilomantsilaisia, jotka ovat antaneet aikaansa tutkimukselle, mikä on epäilemättä voinut vaikuttaa artikkelin sanavalintoihin. Aineisto on ainutlaatuista: se tavoittaa jotain menneestä karjalankielisyydestä ja samalla tekee sitä näkyväksi nykypäivän kielenkäyttäjille.

Tutkimuksessa rajakarjalaistaustaiset haastateltavat ovat saaneet kuunneltavakseen saman murrenäytteen, jota heitä on pyydetty imitoimaan. Esimerkiksi eräs haastateltavista, Irina, vaikuttaa olevan "synnynnäinen kielentarkkailija", ja hänellä on tarkka kielikorva, mikä käy ilmi myös Ilomantsin murteen imitoinnissa. Toisen puhujan Teuvon imitaatiot taas osoittavat hänen "pystyvän sekä painamaan mieleensä puheen foneettisia ja prosodisia yksityiskohtia että tuottamaan niitä itse omassa imitaatiossaan" (s. 57). Tutkimusaineiston keruutilanteen kuvaus on olennaisena osana mukana aineiston analyysia. Sen avulla avautuu muun muassa se, miten kieliä on prosessoitu ja millainen pääsy tutkituilla on käsiteltyihin ilmiöihin. Yksittäisten piirteiden nostaminen esiin oli haastateltaville vaikeaa koko aineistossa (s. 53), vaikka muistikuvat itsessään olisivat tarkkoja ja autenttisia, kuten tämän artikkelin haastateltavilla. Eräs puhujista, Helena, kuvaa esimerkiksi, että äidin puheessa oli tietty "rytmi”, kun tutkijat kysyvät äidin ja isän puhetavan eroista. Artikkelissa esitetty pohdinta karjalan kielen puhujuudesta avaa syvällisiä näkökulmia aiheeseen ja korostaa sitä, että piileväkin kielitaito on arvokasta: tutkimukseen haastatellut puhujat ovat säilyttäneet karjalan kieltä, vaikkeivät sitä aktiivisesti arjessaan käytäkään. Karjala on yksi, jopa yllättävän vahva kerrostuma heidän repertuaarissaan.

Artikkeli nostaa myös esiin savolaismurteiden ja karjalan kielen eroja haastateltavilta pyydettyjen vertailujen avulla. Kun puhuja vertaa karjalan kieltä ja Ilomantsin savolaismurretta, artikkelin lukija 
jää kaipaamaan hieman pohdintaa haastateltavan varsin erisävyisen kuuloisista ratkaisuista: Ilomantsin murteella tutkittava ilmaisee asian Tulukkee syömmään ja vällee. Niiku oisitta jo, kun taas karjalaksi hän muotoilee saman Tulkoa lapset syömäh. Tulgoa enämbieze, jottei ruuvat jiähy (s. 65). Ilomantsissa karjalaa on ruvettu arvostamaan ja pitämään matkailuvalttina, ja tämä artikkeli osaltaan tuo tietoisuuteen karjalan ja savon eroavuudet ja sen, kuinka karjalanpuhujat hahmottavat ne.

Erilaisiin kielellisiin resursseihin ja niiden kohtaamiseen liittyy myös Heli Paulaston artikkeli siitä, kuinka luova kielenkäyttö kukoistaa yhteisötaideryhmässä. Tämä on vähemmän tutkittu alue englanti lingua francana (ELF) -tutkimuksessa, mutta sitä olisi syytä tutkia enemmänkin. Artikkelin perusteella leikkisyyden tila, joka syntyy osana taideharrastusta, näyttää madaltavan kynnystä myös kielenkäyttöön, ja sen voi nähdä kannustavan heittäytymään ja luomaan omia kielellisiä normeja sen lisäksi, että ELF-puhujille tämän on todettu olevan ominaista muutenkin (s. 85-86). Artikkeli osoittaa, miten hedelmällistä myös tutkijan on lähteä mukaan aineiston rakentamiseen - senkin uhalla, että joutuu epämukavuusalueelle. Artikkelissa tarkastellulle ryhmälle kielellinen heterogeenisyys on yksi leimallinen piirre, ja sen myötä rakentuu auktoriteettiasemia: toisilta kysytään neuvoa ja uusia sanoja toistetaan osana toimintayhteisössä tapahtuvaa kielenoppimista. Artikkeli tarkastelee sanastossa ilmenevää kieltenvälistä vaikutusta ja valottaa sanastollisten käännösten ja käytön moninaisuutta. Luettelot ja asetelmat selventävät koodinvaihdon funktioita, käännöslainoja, hybridi-ilmauksia sekä muuta kieltenvälistä vaikutusta. Vuorovaikutuksen näkökulma jää toisten tutkimusten aiheeksi, mutta tässäkin artikkelissa on esillä kaksi esimerkkiä, joissa vuorovaikutusta on näytetty karkealla tasolla. Ne olisivat varsin houkuttelevia myös tarkemman analyysin kohteeksi. Tarkoituksena voi olla havainnollistaa toimintayhteisön tilanteita yleisesti, mutta esimerkkien rooli osana tutkimusta sekä jotkin niistä esitetyt tulkinnat herättävät kysymyksiä. Miksi nauru esimerkiksi johtuu idiomin umpisuomalaisuuden tunnistamisesta? Entä millä perusteella ystävän kysymys fraasin tuottamisesta englanniksi on kannustus eikä avoin tiedonhakukysymys? (s. 98) Ilmeisesti tulkinnat nojaavat etenkin etnografiseen tietoon toimintayhteisöstä ja sen tilanteista, minkä olisi voinut tuoda tässä kohtaa esiin täsmentäen. Myös litteraatit mietityttävät vuorovaikutuksen tutkimuksen näkökulmasta, sillä niissä on mahdollisesti yleistajuisuuden vuoksi käytetty osittain ortografian mukaisia merkintätapoja.

Osan kolmannessa artikkelissa "Virtuaalinen amerikansiirtolainen itäsuomalaisessa arjessa katsaus itäsuomalaisen nuoren englannin käyttöön" tutkija on niinikään kerännyt aineiston suoraan tutkittavaltaan. Artikkelin kirjoittaja Esa Penttilä koostaa tutkijan havaintojensa, haastattelun ja tutkitun nuoren, Pekan, päiväkirjamerkintöjen pohjalta lähikuvan siitä, kuinka englanti on 
itäsuomalaisen nuoren arkipäivää virtuaalimaailmassa. Asenne kielitaitoa kohtaan tulee ilmi siinä, että Pekka ei heti kysyttäessä myönnä puhuvansa englantia, ja näyttää mieltävän itsensä yksikieliseksi. Englannin arkikäyttö ei siis tarkoita puhujille välttämättä monikielisyyttä, kuten Penttilä tuo esiin aiemmankin tutkimuksen perusteella (Leppänen ym. 2009).

Amerikansiirtolaiseen Pekkaa verrataan jo otsikossa, joten vertaus saa melko suuren painoarvon. Pekan elämä on virtuaalisesti vahvasti kaksikielistä, mutta toisaalta koulunkäynti tapahtuu pitkälti suomeksi, ja samoin kotikielenä on suomi. Englannin Pekka on oppinut kouluikäisenä, kuten toisen polven amerikansiirtolaiset; Amerikkaan muuttanut ensimmäinen polvi saattoi pärjätä pelkällä suomellakin (ks. Jönsson-Korhola 2003). Verkko yhdistää ja siirtää ihmisen jonnekin toiseen yhteiseen todellisuuteen, virtuaaliseen "kotimaahan" (s. 135), jossa fyysinen paikka menettää merkitystään, kun todellisuus rakentuu yksilöllisesti henkilön kiinnostuksenkohteiden mukaan. Penttilä kuvaa suhdetta virtuaalimaailmaan diasporisena asenteena tai projektina (diasporic stance, project; Brubaker 2005: 13), joka on vapaaehtoinen ja käänteinen: yksilö ei suuntaudu entiseen kotimaahansa vaan uuteen maailmaan, jossa viettää suuren osan ajastaan. Tutkimuksen Pekka on siis varsin uskottavasti virtuaalinen siirtolainen, joka elää eri todellisuuksissa limittäin. Yhtymäkohtia sadan vuoden takaiseen amerikansiirtolaiseenkin on.

Penttilän tutkimus tarkastelee Internetissä toteutuvaa verkottunutta monikielisyyttä, joka ylittää ja sivuuttaa perinteiset kansakuntarajat. Niinpä myöskään itäsuomalaisuus ei ole tästä näkökulmasta merkittävä tekijä, vaan Pekka voisi kirjoittajan mukaan asua missä päin Suomea tahansa. Itäsuomalaisuus tulee kuitenkin esiin epäsuorasti haastattelukatkelmissa käytetystä kielestä. Itäsuomalaisesta lähtökohdasta kirjoituksessa kommentoidaan myös venäjän roolia Pekan kieliympäristössä, sillä paikkakunnalla käy venäjää puhuvia turisteja ja asuu venäläistaustaisia maahanmuuttajia. Pekka ei kuitenkaan mainitse venäjää missään vaiheessa haastattelua, eikä tutkijakaan ole katsonut tarpeelliseksi siitä erikseen kysyä.

\section{Historiallisia ikkunoita monikielisyyteen}

Toisen osan artikkelit tulkitsevat ja yhdistelevät historiallisia ja elämäkerrallisia lähteitä. Milla Uusitupa ja Vesa Koivisto tarkastelevat artikkelissaan "Monikielinen Raja-Karjala" alueen eri kieliä erityisesti 1800-luvun lopulta viime sotiin asti, jolloin aluemuutokset hajottivat karjalanpuhujat uusille alueille. Aineistona on sekä vanhoja murrenauhoituksia että historiantutkimusta ja kaunokirjallisuutta. Näiden pohjalta kirjoittajat hahmottelevat kuvaa siitä, miten eri kielet elivät rinnakkain ja sekoittuivat erilaisissa käytännön tilanteissa kuten kaupankäynnissä, kirkollisissa 
yhteyksissä tai koulutuksessa. Aineiston aiempi tuntemus auttaa kirjoittajia tässä työssä, ja tuloksena on monipuolinen kuva, johon haastattelukatkelmien fragmentaariset havainnot on saatu elävöittävästi mukaan. Kaunokirjallisten tekstien rooli suhteessa muuhun aineistoon jää kuitenkin hieman taustalle.

Murrehaastatteluissa on varsin vähän suoria kysymyksiä itse kielistä, joten niiden käytöstä on myös "välttämätöntä olettaa", kuten kirjoittajat toteavat (esim. s. 145). Esimerkiksi haastatteluissa esitetyt venäjänkieliset repliikit paljastavat uittotyömaiden komentokielen (s. 166). Artikkelissa joudutaankin ottamaan huomioon maallikoiden käyttämien käsitteiden merkitys ja kirjavuus, kun "suomella" voidaan viitata karjalaan ja "venäjä" voi tarkoittaa sekä kirkkoslaavia että venäjää.

Artikkelissa tehdään ero kielimaisematutkimukseen, mutta pohtia voi, kuinka tarpeellista kielimaisema-sanan käyttö on sekä laveasti että termimäisesti, teoksessa kun on myös varsinaista kielimaisematutkimusta edustava Kolehmaisen artikkeli. Kielimaiseman käsite toistuu muuallakin kokoelmassa. Ilmaus on populaari ja sinänsä kuvaava, mutta usein kielitilanne, -olot tai -valikoima toimisi kielimaiseman ohella yhtä hyvin, jopa paremminkin.

Osan toisessa artikkelissa Pekka Kujamäki avaa sotien monikielisyyttä, joka jää usein näkymättömiin. Keskiössä on kaksi sodanaikaista tulkiksi päätynyttä henkilöä ja heidän päiväkirjamerkintänsä, ja artikkelin kerronta imee mukaansa kuin romaani. Jatkosodassa tulkeille oli kysyntää esimerkiksi silloin, kun Suomeen saapui saksalaisia sotilaita. Artikkeli kuvaa myös jossain määrin tulkin oppimista toimeensa. Kielten kohtaaminen sodassa on monipuolinen ja varsin strateginen tutkimuskohde, ja nämä yksilölliset tarinat valottavat tätä hyvin, mutta samalla on muistettava aineiston subjektiivisuus ja syntyaika, kuten kirjoittaja painottaa (s. 192-193).

\section{Kieliä Twitterissä ja hautausmailla}

Kolmannessa osassa on niinikään kaksi artikkelia, joissa Mikko Laitinen, Heli Paulasto ja Lea Meriläinen ovat tutkineet englantia itäsuomalaisessa tviittivirrassa ja Leena Kolehmainen Varkauden hautausmaiden kielimaisemaa. Ensi silmäyksellä varsin erilaiset tutkimukset on yhdistetty saman otsikon alle, ja lopputulos on piristävä: nykyajan tviittivirran kielet ja hautausmaan muistokivet kertovat omalla laillaan yhteiskunnasta sekä kielten ja kielisuhteiden muutoksesta eri aikoina.

Laitisen, Paulaston ja Meriläisen teksti edustaa digitaalista kielentutkimusta, ja aineistona on viiden itäsuomalaisen maakunnan alueelta lähetetyt Twitter-viestit. Massadata tarjoaa monenlaisia 
tutkimusmahdollisuuksia, joista artikkelissa yhdistetään kaksi tapaustutkimusta. Ensinnäkin tutkitaan sitä, millä kielillä itäsuomalaiset kirjoittavat Twitterissä, toiseksi sitä, miten aineiston englanninkielisissä viesteissä käytetään apuverbien muotoja. Suurin osa tviiteistä on siis englannin ei-äidinkielisiltä puhujilta, joiden osoitetaan kuitenkin omalta osaltaan vievän englannin kielessä olevia muutoksia eteenpäin. Artikkelin kirjoittajien lähtökohta on variationistinen, jolloin taustaajatuksena on se, että monikielinen henkilö valitsee kahden samanarvoisen koodin, esimerkiksi suomen ja englannin, välillä, eikä tämä valinta muuta viestin sisältöä.

Kirjoittajat toteavat tutkimuksensa vahvistavan vuonna 2007 tehdyn kansallisen kyselytutkimuksen (Leppänen ym. 2009) tuloksia englannin kielen käytöstä siinä, että englantia käytetään suhteellisesti enemmän suurilla kuin pienillä paikkakunnilla. Toisaalta tutkimus osoittaa jakolinjan häilyvyyden ja paikkakuntien heterogeenisyyden, mikä tarjoaa mielenkiintoisia aiheita laadulliseen tutkimukseen; kirjoittajat väläyttävät jatkotutkimusaiheena esimerkiksi kielivalinnan erilaisissa sosiaalisissa konteksteissa (s. 262). Artikkeli tarjoilee nykyisen monikielisyyden ymmärtämiseen suuria linjoja, ja tätä vahvistaa myös kahden teeman, kielivalinnan ${ }^{1}$ ja kielenpiirteiden tarkastelun yhdistäminen: massadatan pohjalta asioita voi sanoa ytimekkäästi ja näyttää monikielisyydestä jotain uutta. Aineiston kokoamista erilaisine rajoitteineen kuvataan seikkaperäisesti.

Kirjan viimeisenä on Leena Kolehmaisen artikkeli, joka kuvaa historiallista monikielisyyttä Varkaudessa. Se edustaa Suomessa uutta hautausmaiden kielimaisematutkimusta ja tarjoaa tarkasteltavaksi monikerroksisen ajallisen aineiston, joka avaa kielisosiologisia ulottuvuuksia menneisyydestä. Hautakiviin tallentunut kieli kertoo muun muassa tekstilajin konventioiden muutoksesta ajan saatossa: nykyään hautakiveen kirjoitettavat tekstit ovat vähentyneet tasaarvoistumisen myötä, mutta tilalle on tullut esimerkiksi kuvia.

Hautakivissä on valtaosin suomea; seuraavaksi eniten on ruotsia ja lisäksi yksittäisinä tapauksina latinaa, saksaa ja venäjää. Esiin nousee myös se, kenen kieliä muistomerkeissä on: pystyttäjien, vainajan, ohikulkijoiden vai ehkä virallisten instituutioiden? Esimerkiksi Gorohovaja edustaa aineistossa ainoana sanana venäjän kieltä, eikä se ole muistomerkin pystyttäjien vaan kiven valmistajan toimintaympäristön kieli. Useat tekstikatkelmat ovat käännettyjä, eikä monissa muistomerkeissä ole tunnistettavia kieliä, vaan vain nimi ja numeeriset syntymä- ja kuolinaika.

\footnotetext{
${ }^{1}$ Teoksessa esiintyy vaihtelua termien kielivalinta ja kielenvalinta käytössä. Laitisen, Paulaston ja Meriläisen artikkelissa käytetään pääasiassa kielenvalintaa, joka on myös koko teoksessa hakusanana. Hakusanoista puuttuu kuitenkin kielivalinta, jota on käytetty teoksessa kielenvalintaa useammin.
} 
Esillä oleva aineisto myös näyttää, että Varkauden hautausmaat ovat suomenkielistyneet ja kielellinen monimuotoisuus on tältä osin kaventunut.

Hautakiveen kirjoitettu teksti voisi Kolehmaisen mukaan olla vainajan elämän motto (Mitä ajattelet, siksi tulet), jollaisena voi yhtä hyvin näyttäytyä myös aineistossa esiintyvä sitaatti Raamatusta (Christus är mit lif och döden är min winning. Phil. ep. 1:21), vaikka kirjoittaja esittääkin, että se olisi rukous vainajan puolesta (s. 300). Myös teksti SIEL TURVAS ONPI PAREMPI, KUN ISÄN ÄIDIN TÄÄLLÄ on artikkelissa luokiteltu toiveeksi, mutta senkään tulkinta ei avaudu yksiselitteisesti. Tekstien moniäänisyys ja -kerroksisuus on ilmeistä, eivätkä tulkinnatkaan ole ilmiselviä. Puhutellaanko vainajaa, kuvataanko häntä ohikulkijalle, vai voisiko sitaatti olla ikään kuin vainajan suulla lausuttu? Persoonamuotojen tarkastelu voisi joka tapauksessa olla yksi lisänäkökulma tekstin tulkintaan.

\section{Arkinen monikielisyys näkyväksi}

Kirjan lukijakunnasta esipuheessa on erikseen mainittu "itäsuomalainen lukija", mutta muitakaan lukijoita ei ole unohdettu. Teos pyrkii selvästi tavoittamaan laajempaa yleisöä, mutta samalla toimittajat toivovat, että se toimisi inspiraation lähteenä uusille tutkimuksille. Innostavia tulevaisuuden tutkimusaiheita teoksessa onkin, kuten edellä on jo käynyt ilmi. Kirja voi vedota eritaustaisiin lukijoihin, jotka voivat valikoidenkin saada siitä itseään kiinnostavaa tietoa puhujien yksilöllisistä valinnoista ruohonjuuritason tilanteissa sekä samalla uusia ajatuksia kielten merkityksistä yhteiskunnassa ja kytköksistä toisiinsa. Pyrkimys yleistajuisuuteen voi osittain vaikuttaa joihinkin ratkaisuihin, jotka herättävät kysymyksiä, mutta samalla yleistajuisuus tuo kirjaan kiinnostavuutta. Teoksen fokus ja vahvuus onkin monikielisyyden myyttien purkamisessa ja aihepiirien yhdistelemisessä.

Kokoelman artikkelit näyttävät näkymätöntä monikielisyyttä: ne tavoittavat historiaan jäänyttä monikielisyyttä, johon ei aiemmin ole kiinnitetty erityistä huomiota, kyseenalaistavat käsityksiä kielitaidon riittävyydestä ja osoittavat, että nykyajan monikielisyys ei ole pelkästään englantia, vaikka englantia käytettäisiinkin lingua francana. Pääasiassa englantia käsittelevät artikkelit alleviivaavat tätä sekä tuovat esiin englannin variaatiota. Kirja nostaa esiin erilaiset normit ja purkaa myös syntyperäisen kielenpuhujan ihannetta: ei-syntyperäiset kielenkäyttäjät luovat omia normejaan, ja kieli elää ja muuttuu tarpeiden mukaan. Joskus variaatiota täytyy kuitenkin erikseen kaivaa näkyville, ja näin tapahtuu tässä teoksessa. Itä-Suomeen helposti mielikuvissa yhdistyvä 
venäjä puolestaan on läsnä taempana, lähinnä osana historiaa. Nykykontaktit venäjän kielen kanssa jäävät uusien tutkimusten aiheiksi.

Kirja avaa toisiaan täydentäviä näkökulmia kielen osaamisesta ja käytöstä muuttuvissa tilanteissa. Kun kieli on uhanalainen, sen osaaminen voi olla pinnan alla, piilevänä, kuten karjalan tapauksessa. Toisaalta yhteinen toiminta luo tilaisuuksia toimia tietyllä kielellä, jopa yllyttää siihen, vaikka vähäisemminkin resurssein; sen osoittavat tutkimukset koululaisen peliarjesta, yhteisötanssiryhmästä ja sota-ajan tulkeista. Monikielisyys voi olla arjessa etäinen tai turhan ylevästi latautunut käsite, mutta teos näyttää sen toteutumisesta Itä-Suomessa monia puolia, niin historiassa kuin nykypäivänä, virallisesti kuin epävirallisestikin.

Kaarina Hippi

etunimi.sukunimi@oulu.fi

Kirjoittaja on tutkijatohtori Oulun yliopistossa ja vieraileva tutkija Helsingin yliopistossa.

\section{Lähteet}

BRUBAKER, ROGERS 2005: The 'diaspora' diaspora. - Ethnic and Racial Studies 28 s. 1-19. JÖNSSON-KORHOLA, HANNELE 2003: Pussaa se peipipoki kitsistä petiruumaan. Suomalaiset ja suomen kieli Amerikassa. - Hannele Jönsson-Korhola ja Anna-Riitta Lindgren (toim.), Monena suomi maailmalla. Suomalaisperäisiä kielivähemmistöjä s. 386-448. Tietolipas 190. Helsinki: Suomalaisen Kirjallisuuden Seura.

LEPPÄNEN, SiRPA - PitKÄNEN-Huhta, ANNE - NikUla, TARJA - KytÖlÄ, SAMU - TÖRMÄKANGAS, TIMO - Nissinen, KARI - KÄÄNTÄ, LeILA - ViRKKULA, TIINA - LAITINEN, MikKO - PAHTA, PÄIVIKOSKELA, HEIDI - LÄHDESMÄKI, SALLA - JOUSMÄKI, HENNA 2009: Kansallinen kyselytutkimus englannin kielestä Suomessa. Käyttö, merkitys ja asenteet. Jyväskylä: Jyväskylän yliopisto. http://urn.fi/URN:ISBN:978-951-39-3815-4. 